\title{
THE ROLE OF REGULATORY T LYMPHOCYTES IN IMMUNE CONTROL OF MC-2 FIBROSARCOMA
}

\author{
Tomislav Jukić ${ }^{1}$, Ana Jurin Martić, ${ }^{2,3}$, Siniša Ivanković ${ }^{4}$, Mariastefania Antica ${ }^{5}$, \\ Doroteja Pavan Jukić ${ }^{6}$, Cecilija Rotim ${ }^{7}$ and Mislav Jurin ${ }^{4}$
}

${ }^{1}$ Faculty of Medicine, Josip Juraj Strossmayer University of Osijek, Department of Internal Medicine, Family Medicine and History of Medicine, Osijek, Croatia;

${ }^{2}$ Čakovec County Hospital, Čakovec, Croatia;

${ }^{3}$ Faculty of Dental Medicine and Health, Josip Juraj Strossmayer University of Osijek, Osijek, Croatia; ${ }^{4}$ Rudjer Bošković Institute, Division of Molecular Medicine, Zagreb, Croatia;

${ }^{5}$ Rudjer Bošković Institute, Division of Molecular Biology, Zagreb, Croatia;

${ }^{6}$ Faculty of Medicine, Josip Juraj Strossmayer University of Osijek,

Department of Department of Gynecology and Obstetrics, Osijek, Croatia;

${ }^{7}$ Dr Andrija Štampar Teaching Institute of Public Health, Zagreb, Croatia

\begin{abstract}
SUMMARY - The role of T regulatory lymphocytes $\left(\mathrm{T}_{\text {reg }}\right)$ particularly in cancer is well known. The goal of the present study was to determine the contribution of these lymphocytes in the regulation of anti-tumor immunity of $\mathrm{CBA} / \mathrm{HZgr}$ mice against MC-2 fibrosarcoma (4 $4^{\text {th }}$ generation of methylcholanthrene induced tumor). The levels of $\mathrm{T}$ lymphocytes (CD4+, CD8+ and CD4+CD25+) were determined 8 and 20 days after tumor transplantation. Further, the role of CD4+CD25+ $\left(\mathrm{T}_{\text {regs }}\right)$ in tumor-host interaction was evaluated in vitro and in vivo by using specific monoclonal antibodies. We found that splenocytes of both control and $\mathrm{T}_{\mathrm{reg}}$ depleted tumor bearing mice strongly but differently inhibited growth of tumor cells in vitro. While splenocytes of untreated mice exhibited significant decrease of this activity (from $74.4 \%$ to $62.6 \%$ and $32.95 \%$ ), the splenocytes of $\mathrm{T}_{\text {reg }}$ depleted mice showed increase of this activity (from 79.5\% to $84.3 \%$ and $86.2 \%$ ) from day 6 to day 13 and day 21 after tumor grafting, respectively. Further, upon i.v. injecting specific monoclonal anti- $T_{\text {re }}$ antibody tumor immediately prior to tumor cell intracutaneous transplantation, the tumor was rejected after initial growth. In treated mice, the incidence of $\mathrm{T}_{\text {reg }}$ cells was very low initially, reaching normal values two weeks later. These animals were shown to be resistant to tumor transplantation four months later.
\end{abstract}

Key words: Regulatory T lymphocytes; Tumor growth; Specific monoclonal antibodies; Experimental mice

\section{Introduction}

Immune homeostasis is maintained by regulatory $\mathrm{T}$ cells $\left(\mathrm{T}_{\mathrm{reg}}\right)$ which actively suppress immune response and protect the host against autoimmune diseases ${ }^{1-4}$.

Correspondence to: Prof. Mislav Jurin, $M D, P h D$, Rudjer Bošković Institute, Division of Molecular Medicine, Bijenička 54, HR10000 Zagreb, Croatia

E-mail: jurin@irb.hr

Received December 20, 2019, accepted May 15, 2020
These cells have been described as CD4+CD25+, characterized by the expression of IL2 receptor (CD25 molecule) and the costimulatory molecule $\mathrm{CD} 4{ }^{5} . \mathrm{T}_{\text {regs }}$, acting as immune suppression for body tissues, have been demonstrated to play an essential role in selftolerance, transplantation, allergy and tumor/microbial immunity ${ }^{6}$. Indeed, accumulating evidence implicates $\mathrm{T}_{\text {regs }}$ as one of the principal cell types suppressing TAA-specific lymphocyte activity and tumor eradication, and thus one of the major obstacles to effective 
anti-tumor immunotherapy ${ }^{7-10}$. CD25+CD4+ regulatory $\mathrm{T}$ cells $\left(\mathrm{T}_{\text {reg }}\right)$ comprise $5 \%-10 \%$ of the circulating CD4+ $\mathrm{T}$ cell population and suppress tumor immune responses ${ }^{11}$. Indirect evidence suggests that $\mathrm{CD} 4+\mathrm{CD} 25+\mathrm{T}$ cells $\left(\mathrm{T}_{\text {regs }}\right)$ are important in suppressing TAA-specific immunity ${ }^{12,13,}$, and they suppress nonspecific $\mathrm{T}$ cell responses in vitro. It is critical that the mechanism that contributes to $T_{\text {reg }}$ accumulation in tumors is not fully understood. It has been suggested that $\mathrm{T}_{\text {regs }}$ display an enhanced capacity for infiltration of, and accumulation within the tumor in comparison to effector $\mathrm{T}$ cells ${ }^{7}$.

It was shown that $T_{\text {reg }}$ cells were activated through their $\mathrm{T}$-cell receptors in antigen-specific manner but they can inhibit effector cells in an antigen-unspecific way $^{6-8}$. Further, human and murine $\mathrm{T}_{\text {reg }}$ cells were shown to secrete immunosuppressive cytokines ${ }^{9-11} \mathrm{~T}_{\text {reg }}$ cells could have beneficial effects in the body by preventing autoimmune diseases but, on the other hand, they act against the body by suppressing host's immune reaction against tumor ${ }^{1,12,13}$. CD25+ is overexpressed in certain lymphoid malignancies, on activated $\mathrm{T}$ cells involved in autoimmune disorders, and in allograft rejection. Increased CD25+ expression has been demonstrated in anaplastic large-cell lymphoma, adult T-cell leukemia (ATL)/lymphoma, chronic lymphocytic leukemia, cutaneous T-cell lymphoma, hairy cell leukemia, some B-cell non-Hodgkin's lymphomas, and Hodgkin's lymphoma ${ }^{14}$.

Several reports have pointed to pronounced depletion of $\mathrm{T}_{\text {reg }}$ cells after application of specific monoclonal antibodies in several mouse tumor models, resulting in slow tumor growth and prolonged survival of treated animals ${ }^{15,16}$. The immune system in higher vertebrates protects the body against a wide and changeable spectrum of pathogenic organisms or antigens, while complex mechanisms in the thymus and peripheral lymphoid organs prevent reaction to the host's own (self) antigens ${ }^{1-4,17}$. Suppressor activity of regulatory $\mathrm{T}$ lymphocytes characterized as CD4+CD25+ is necessary for this tolerance of self antigens ${ }^{4,18}$. An important mechanism involves the action of regulatory $\mathrm{T}$ cells to maintain immune balance of the organism to be tolerant to self, while remaining competent to mount an effective immune response against third party antigens ${ }^{3,4}$. The activities of the immune system play an important role in the relations between a host and its tumor. Numerous clinical and experimental data point to a specific immune reaction against a growing tumor and it is likely that these immune responses develop in much the same way as they do to pathogens or foreign antigens ${ }^{3,12}$. Thus, anti-tumor antibodies and $\mathrm{T}$ cells are generated and, along with nonspecific immune mechanisms, play a role in tumor immunity. Further, it should be mentioned that a growing tumor, by releasing particular cytokines, may be immunosuppressive and may stimulate production of regulatory $\mathrm{T}$ lymphocytes ${ }^{19-21}$.

The anti-CD25 monoclonal antibody is one of the most used treatments for steroid-refractory graft-versus-host disease (GVHD) and could selectively inhibit activated $\mathrm{T}$ cells, and therefore does not increase the risk of relapse of leukemia. The study by Tao et al. showed that CD25+ lymphocyte proportion significantly decreased after anti-CD25 monoclonal antibody treatment, suggesting that $\mathrm{CD} 25+$ lymphocytes were strongly inhibited ${ }^{22}$.

We performed in vitro and in vivo experiments by using specific anti-CD25 monoclonal antibody in our well defined mouse tumor model, $\mathrm{CBA} / \mathrm{HZgr}$ mice and $\mathrm{MC}-2$ transplanted fibrosarcoma ( ${ }^{\text {th }}$ generation of methylcholanthrene induced tumor) with known dynamics of $\mathrm{T}$ cells in tumorous mice. Actually, lymphoid cells from tumor bearing mice were in a classical colony inhibition test treated with specific anti-CD25 monoclonal antibody and cultivated with tumor cells. For in vivo studies, the mice with transplanted tumor were treated with specific anti-CD25 monoclonal antibody. The incidence of particular $\mathrm{T}$ cell populations, tumor growth curves and animal survival were determined.

\section{Methods}

\section{Experimental animals}

Male mice of $\mathrm{CBA} / \mathrm{HZgr}$ strain were obtained from Animal Breading Unit of Ruđer Bošković Institute (Zagreb, Croatia). At the beginning of the experiment, the animals were about three months old with body weight 20-22 g. They were kept in plastic cages of five mice each. Admission to food (4 RF $21 \mathrm{GPL}$ Mucedola srl, Italy) and tap water was ad libitum. The temperature of the room with experimental animals was $22^{\circ} \mathrm{C}$, humidity $55 \%$ and light-dark intervals exchanged every 12 hours. All experiments were per- 
formed in accordance with the Croatian act on animal welfare.

\section{Tumor}

Fibrosarcoma MC-2 was used in the experiments. The tumor was induced by injecting methylcholanthrene dissolved in olive oil subcutaneously into CBA/ $\mathrm{HZgr}$ female mouse. We have several generations of the tumor in our tumor bank. The tumor of the $4^{\text {th }}$ generation was used in all experiments.

Tumor cell suspension was mechanically prepared from growing tumor as described previously ${ }^{23}$, with $10^{7}$ viable cells in $1 \mathrm{~mL}$. The mice were injected subcutaneously with $0.1 \mathrm{~mL}$ of the suspension ( $10^{6}$ viable cells) and, in the experiments with monoclonal antibody, $10^{5}$ cells were injected intracutaneously. By using the caliper (Cambridge, USA), three orthogonal diameters (A, B and $\mathrm{C}$ ) of growing tumor were determined every three days. Tumor volume was determined by using the $\mathrm{ABC} \pi / 6$ formula.

For in vitro experiments, tumor cell suspension was cultivated in RPMI media (Institute of Immunology, Zagreb, Croatia) supplemented with $10 \%$ of fetal calf serum (FCS) (Sigma, USA). The cell cultures were kept in the incubator (Heraeus, Germany) at $37{ }^{\circ} \mathrm{C}$ in humid atmosphere with $5 \%$ of $\mathrm{CO}_{2}$.

\section{Lymphocyte spleen cell suspension}

On particular days after tumor transplantation, the mice were sacrificed, spleens removed, single cell suspension prepared mechanically and lymphocytes were isolated on a density gradient by using Lymphoprep ${ }^{24}$.

\section{Determination of lymphocyte populations}

Spleen lymphocytes were washed once in phosphate buffered saline (PBS) pH 7.3 with 5\% FCS adjusted to final concentration of $1 \times 10^{6} \mathrm{cell} / \mathrm{mL}$ and incubated with particular monoclonal antibodies for 30 minutes on ice in dark. Monoclonal antibodies antiCD3, anti-CD4, anti-CD8 and anti-CD25, as phycoerithrin or FITC conjugate (BD Pharmingen Bioscience, USA) and corresponding isotype controls were used. The cells were washed in PBS, centrifuged at 200xg for 5 minutes and resuspended in PBS with 5\% FCS. All samples were finally resuspended in a propidium iodide $(1 \mu \mathrm{g} / \mathrm{mL})$ containing buffer.

\section{Flow cytometric analysis}

The fluorescence intensity at the single cell level was evaluated by flow cytometry (FACScalibur, Becton Dickinson, Mountain View, USA). For each sample, 10,000 cells were analyzed. Fluorescence signals were recorded on a frequency histogram or dot plot using logarithmic amplification. Cells were considered unstained if the associated fluorescence did not differ from the fluorescence of cells labeled with isotype control (negative control). Nonviable cells labeled with propidium iodide were excluded from analysis.

\section{Cultivation of tumor cells with lymphocytes}

Microplates with 96 wells (Greiner, Germany) were used. Tumor cell suspension from the culture was prepared to contain $8 \times 10^{3}$ viable cells in $1 \mathrm{~mL}, 0.1 \mathrm{~mL}$ poured in each well complemented with $5 \times 10^{5}$ lymphocytes, and tumor cell number was determined by using an inverse microscope (Zeiss, Germany) three days later, as described previuously ${ }^{17}$.

Specific monoclonal antibody 7D4 (BD Pharmingen Bioscience, USA) was used to eliminate CD4+CD25+ cells from lymphocyte suspension. Briefly, $10^{6}$ lymphocytes were incubated with $1 \mu \mathrm{g}$ of 7D4 antibody at $4{ }^{\circ} \mathrm{C}$ during 1 hour, followed by centrifugation $(150 \mathrm{xg})$ for 10 minutes, resuspended in the medium and cultivated at $37{ }^{\circ} \mathrm{C}$ for an additional hour. Double washing with the medium (150xg for 5 minutes) was performed and, in the presence of monoclonal antibody hybridoma PC61 (which does not compete with 7D4 antibody), it was confirmed that there was less than $0.1 \%$ of lymphocytes with CD25 antigen.

\section{Monoclonal antibody application in tumor transplanted mice}

The anti-CD25 monoclonal antibody (clone PC61, rat anti mouse; Pharmingen Biosciences, USA) was injected $(0.25 \mathrm{mg}$ in $0.2 \mathrm{~mL}$ of the Hanks solution) intravenously (i.v.) in the mice immediately prior to intracutaneous injection of $10^{5}$ viable tumor cells. Control animals were injected with rat immunoglobulins of the same manufacturer.

\section{Statistical analysis}

Mean values and standard deviations were determined for each of the experimental groups. Significanc- 
es were determined by using ANOVA and Tukey posthoc test. Statistical significance was defined as $\mathrm{p}<0.05$.

\section{Results}

\section{Dynamics of Tlymphocyte populations during tumor growth}

The CBA/HZgr mice were transplanted with MC-2 fibrosarcoma cells. Eight or 20 days later, the animals with growing tumor were sacrificed, spleen cell suspensions prepared, lymphocytes isolated and the incidence of CD4+, CD8+, as well as CD4+CD25+ T cells determined by using specific monoclonal antibodies. There

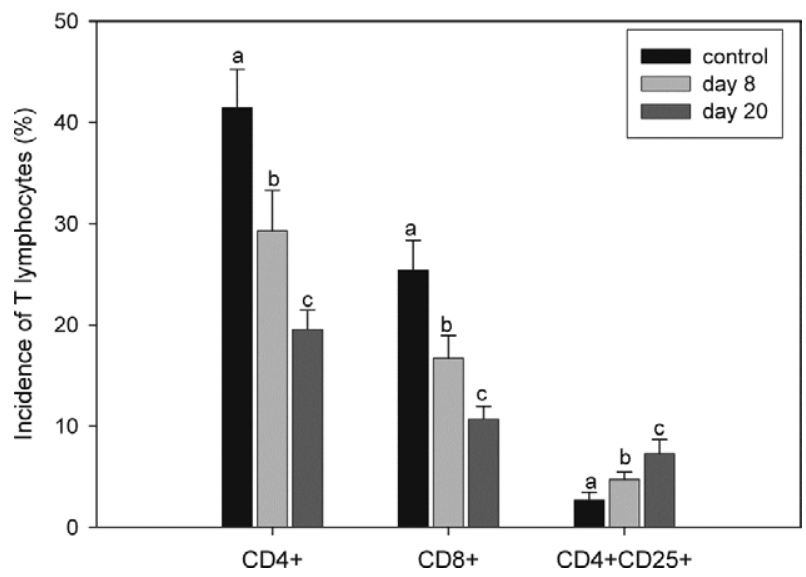

Fig. 1. Incidence of $C D 4+, C D 8+$ and $C D 4+C D 25+$ lymphocytes in the spleen of $C B A / H Z$ gr mice transplanted with fibrosarcoma $M C-2$, determined on particular days during tumor growth. Small letters above bars indicate significant differences among the groups $(p<0.01)$. were seven mice in each group of tumor-transplanted mice and seven control mice without tumor.

The results are presented in Figure 1. As shown, the incidence of CD4+ and CD8+ cells decreased whereas the $\mathrm{CD} 4+\mathrm{CD} 25+$ incidence increased during tumor growth. Differences between control and tumor bearing mice were significant $(\mathrm{p}<0.01)$.

Besides, about $10 \%$ of all CD4+ cell populations were $\mathrm{CD} 4+\mathrm{CD} 25+$ cells, which is consistent with the data already known.

\section{The influence of specific anti-CD25 monoclonal antibodies against the tumor determined in vitro and in vivo}

For in vitro experiments, lymphocytes were isolated from the spleen of CBA/HZgr mice transplanted with MC-2 fibrosarcoma cells and sacrificed 2, 6, 13 and 21 days later. Tumor cells were cultivated with the lymphocytes isolated from tumor bearing and from normal mice. Furthermore, the 7D4 monoclonal antibody was used to remove CD25+ cells from lymphocyte population. As presented in Table 1, the lymphocytes from tumor bearing mice were effective in destroying tumor cells, but the bigger the tumor, the less effective the lymphocytes were $(74.4 \%, 62.6 \%$ and $32.1 \%$ of control values). However, the elimination of CD25+ cells resulted in well pronounced anti-tumor activity of lymphocytes isolated from tumor bearing mice regardless of tumor size (79.5\% to $86.2 \%$ of control values).

For in vivo experiments, the anti-CD25 (clone PC61) monoclonal antibody (rat anti mouse) was injected i.v. into $\mathrm{CBA} / \mathrm{HZgr}$ mice transplanted intracutaneously with MC-2 fibrosarcoma cells immediately

Table 1. Fibrosarcoma MC-2 cell count determined 3 days after cultivation with lymphocytes from normal or tumor bearing mice, cultivated in microplates. Lymphocytes from tumor bearing mice were collected on particular days after tumor transplantation and in one group CD25+ cells were eliminated

\begin{tabular}{|l|l|l|l|l|l|}
\hline \multirow{2}{*}{$\begin{array}{l}\text { Days after } \\
\text { tumor }\end{array}$} & $\begin{array}{l}\text { Tumor } \\
\text { volume } \\
\text { transplantation }\end{array}$ & \multicolumn{4}{|c|}{ Fibrosarcoma MC-2 cell count } \\
\cline { 3 - 6 } & $\left(\mathrm{mm}^{3}\right)$ & $\begin{array}{l}\text { MC-2 cells } \\
\text { only }\end{array}$ & $\begin{array}{l}\text { MC-2 cells }+ \\
\text { lymphocytes from } \\
\text { normal mice }\end{array}$ & $\begin{array}{l}\text { MC-2 cells }+ \\
\text { lymphocytes from } \\
\text { tumor bearing mice }\end{array}$ & $\begin{array}{l}\text { MC-2 cells + } \\
\text { lymphocytes from tumor bearing } \\
\text { mice (CD25+ eliminated) }\end{array}$ \\
\hline 2 & 0.0 & $103.2 \pm 3.3$ & $104.0 \pm 3.1$ & $102.9 \pm 2.9$ & $103.2 \pm 3.3$ \\
6 & 8.4 & $99.7 \pm 2.0$ & $100.1 \pm 2.9$ & $25.6 \pm 2.1$ & $20.5 \pm 2.1$ \\
13 & 326.4 & $89.1 \pm 2.0$ & $87.8 \pm 3.1$ & $32.8 \pm 3.1$ & $13.8 \pm 2.4$ \\
21 & 2216.8 & $102.6 \pm 3.0$ & $103.6 \pm 2.6$ & $69.8 \pm 2.4$ & $14.3 \pm 2.9$ \\
\hline
\end{tabular}




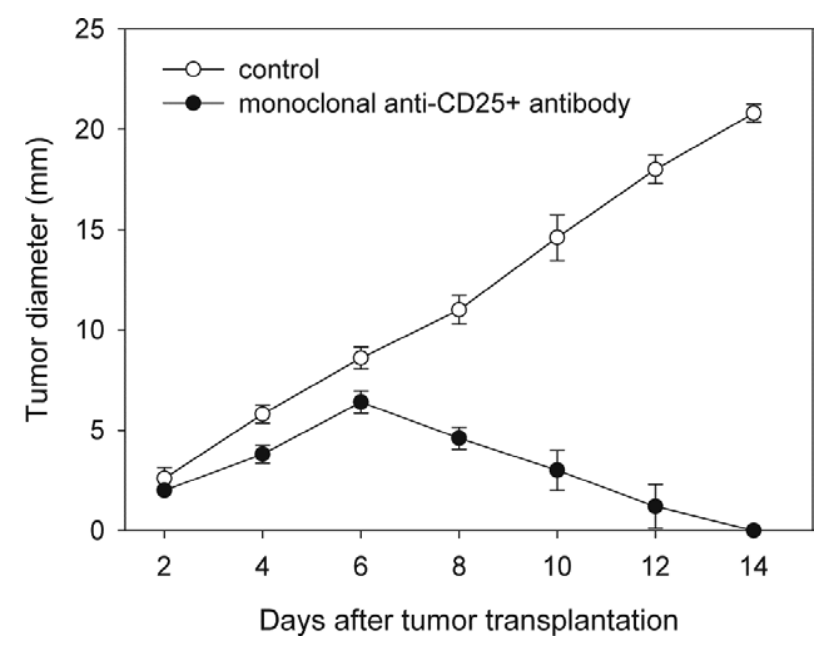

Fig. 2. Tumor growth curves after fibrosarcoma $M C-2$ cell intracutaneous injection to $C B A / H Z g r$ mice. The mice were intravenously injected either with monoclonal antiCD25 antibody (rat anti mouse) or with normal rat immunoglobulins immediately prior to tumor transplantation. There were five mice per group.

after antibody application. Tumor control mice were injected with normal rat serum. As shown in Figure 2, initial tumor growth occurred in both groups, i.e. in five mice from each group. However, after day 6, tumor regression was noticed in the specific monoclonal antibody treated group, whereas in the control group it was growing. Injection of specific monoclonal antibody at different times with regard to tumor application was not successful (data not shown).

The mice that rejected the tumor following antiCD25 monoclonal antibody treatment were transplanted with $10^{6}$ viable tumor cells four months later. However, the tumor did not develop. Furthermore, as illustrated in Figure 3, the incidence of CD4+CD25+ lymphocytes was very low in monoclonal antibody treated mice in comparison to the results shown in Figure 1, while the incidences of CD4+ and CD8+ cells were normal throughout the observation period. It should be noted that the incidence of CD4+CD25+ lymphocytes in these mice determined 14 days after tumor transplantation reached the values observed in control mice (see Fig. 1).

\section{Discussion}

The CD25+ lymphocytes with their IL-2 receptor are a critical non-redundant regulator of immune ho-

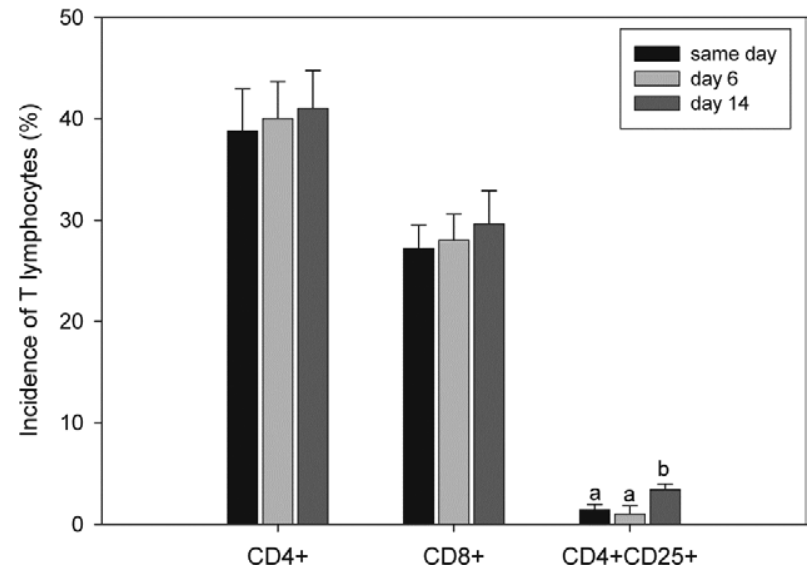

Fig. 3. Incidence of CD4+, CD8+ and CD4+CD25+ lymphocytes on particular days in the spleen of CBA/ HZgr mice transplanted intracutaneously with fibrosarcoma $M C-2$ cells and intravenously with monoclonal anti-CD25 antibody (rat anti mouse) immediately prior to tumor transplantation. Small letters above bars indicate significant differences among the groups $(p<0.01)$.

meostasis. There is increasing interest in the therapeutic role of IL-2 signalization to promote immune activation in tumor immunotherapy or enhance immune suppression in transplantations, autoimmunity and inflammatory disease ${ }^{25}$.

Adoptive cell therapy is an emerging treatment strategy for a number of serious diseases. Regulatory $T$ $\left(\mathrm{T}_{\text {reg }}\right)$ cells are a cell type of particular interest for therapy of inflammatory conditions, as they are responsible for controlling unwanted immune responses. The goal of our study was to evaluate the role of CD4+CD25+ $\mathrm{T}_{\mathrm{reg}}$ lymphocytes (in vitro and in vivo) by using specific anti-CD25 monoclonal antibody in a mouse tumor model.

The results presented in this paper indicate that in our experimental model the incidence of anti-tumor lymphocytes, CD4+ and CD8+, decreased while suppressor CD4+CD25+ lymphocytes increased in the spleen of tumor-transplanted mice during tumor growth. This is consistent with the already published results $^{26-28}$. Lymphocytes from tumor bearing mice are cytotoxic against tumor cells in vitro, which is in accordance with our previous and other results ${ }^{29-32}$. As presented, lymphocyte anti-tumor activity decreased with tumor growth and previous results indicate that this activity recovered after tumor elimination ${ }^{31-33}$. 
Furthermore, as presented in this paper, specific monoclonal antibody recovered anti-tumor reactivity of $\mathrm{T}$ lymphocytes by eliminating CD25+ lymphocytes. Similar results on the role of suppressor lymphocytes in tumor-host relation have been published ${ }^{16,34,35}$, pointing to detrimental situation in patients if these cells infiltrate their tumor ${ }^{34,36}$. Son et al. ${ }^{37}$ investigated the potential of anti-CD25 monoclonal antibody to prevent activation of $\mathrm{T}_{\mathrm{reg}}$ lymphocytes during radiation therapy. Anti-CD25 monoclonal antibody inhibited $\mathrm{T}_{\text {reg }}$ lymphocytes and improved the therapeutic effect of irradiation in a mouse model of lung and colon cancer. Combined treatment of anti-CD25 monoclonal antibody with radiation significantly decreased $\mathrm{T}_{\text {reg }}$ in the spleen and tumor compared with control and irradiation only in both lung and colon cancer. Combinatorial treatments resulted in a significant increase in the effector $\mathrm{T}$ cells, longer survival rate, and suppressed irradiated and distal non-irradiated tumor growth ${ }^{37}$.

Moreover, the presented results of our study similarly indicate that the application of specific anti CD25+ antibody to tumor transplanted mice at specific time resulted in normal incidence of CD4+ and CD8+ cells throughout the observation period while the $\mathrm{CD} 4+\mathrm{CD} 25+$ incidence was extremely low during the initial period after antibody and tumor injection. After initial growth, the tumor was rejected and, which is particularly interesting, these mice were resistant to subsequent tumor transplantation. It could be concluded that these animals became resistant to tumor by stimulation of the effector $\mathrm{T}$ cells during tumor growth and that a lower incidence of CD4+CD25+ cells resulted in tumor elimination. Memory cells responsible for antitumor resistance probably developed during transplanted tumor growth and the tumor was eliminated after specific monoclonal anti-CD25+ antibody application at a proper time.

The studies on the role of lymphocytes are fundamental in understanding immune mechanisms in tumor disease. However, the double role of CD4+ T lymphocytes has important clinical implications as CD4 T helper cells keep CD8+ memory cells while CD4+CD25+ cells are important in anti-tumor response inhibition ${ }^{38-41}$. These opposite effects of CD4+ $\mathrm{T}$ lymphocytes call for further investigations on their role in possible clinical approaches. Results suggest that $\mathrm{T}_{\text {reg }}$ depletion strategies may enhance antitumor immunity and additionally improve disease outcomes.

\section{Acknowledgment}

This study was supported by the Ministry of Science, Education and Sports of the Republic of Croatia (grant no. 009899 and 1-08-198).

\section{References}

1. Josefowicz SZ, Lu LF, Rudensky AY. Regulatory T cells: mechanisms of differentiation and function. Annu Rev Immunol. 2012;30:531-64. doi: 10.1146/annurev.immunol.25.022 106.141623

2. Lin X, Chen M, Liu Y, Guo Z, He X, Brand D, et al. Advances in distinguishing natural from induced Foxp $3^{+}$regulatory $\mathrm{T}$ cells. Int J Clin Exp Pathol. 2013;6:116-23. PMC3544233

3. Caridade M, Graca L, Ribeiro RM. Mechanisms underlying CD4+ Treg immune regulation in the adult: from experiments to models. Front Immunol. 2013;4:378. doi: 10.3389/fimmu.2013.00378

4. Gratz IK, Rosenblum MD, Abbas AK. The life of regulatory $\mathrm{T}$ cells. Ann N Y Acad Sci. 2013;1283:8-12. doi: 10.1111/ nyas. 12011

5. Lydyard P, Whelan A, Fanger M. Immunology. $3^{\text {rd }}$ edn. New York and London: Garland Science, 2011.

6. Dunn GP, Old LJ, Schreiber RD. The three Es on cancer immunoediting. Annu Rev Immunol. 2004;22:329-60. doi: 10.1146/annurev.immunol.22.012703.104803

7. Rabinovich GA, Gabrilovich D, Sotomayor EM. Immunosuppressive strategies that are mediated by tumor cells. Annu Rev Immunol. 2007;25:267-96. doi: 10.1146/annurev.immunol. 25.022106.141609

8. Curiel TJ. Regulatory T cells and treatment of cancer. Curr Opin Immunol. 2008;20:241-6. doi: 10.1016/j.coi.2008.04.008

9. Nagraj S, Gabrilovich DI. Tumor escapes mechanism governed by myeloid-derived suppressor cells. Cancer Res. 2008;68: 2561-3. doi: 10.1158/0008-5472.CAN-07-6229

10. He D, Li H, Yusuf N, Elmets CA, Li J, Mountz JD, et al. IL-17 promotes tumor development through the induction of tumor promoting microenvironments at tumor sites and myeloid-derived suppressor cells. J Immunol. 2010;184:2281-8. doi: 10.4049/jimmunol.0902574

11. de Viser KE, Korets LV, Coussens LM. De novo carcinogenesis promoted by chronic inflammation is B lymphocyte dependent. Cancer Cell. 2005;7:411-23. doi: 10.1016/j.ccr.2005.04.014

12. Dasgupta A, Saxena R. Regulatory T cells: a review. Natl Med J India. 2012;25:341-51. PMID: 23998865

13. Ward ST, Hepburn E, Li K, et al. Selective recruitment and retainment of regulatory $\mathrm{T}$ cells in human colorectal cancer. Lancet. 2013;381:s113. https://doi.org/10.1016/S0140-6736 (13)60553-X

14. Janik JE, Morris JC, O'Mahony D, Pittaluga S, Jaffe ES, Redon $\mathrm{CE}$, et al. 90Y-daclizumab, an anti-CD25 monoclonal antibody, provided responses in $50 \%$ of patients with relapsed 
Hodgkin's lymphoma. Proc Natl Acad Sci USA. 2015;112 (42):13045-50. doi: 10.1073/pnas.1516107112

15. Viehl CT, Moore TT, Liyanage UK, Frey DM, Ehlers JP, Ebelein TJ, et al. Depletion of CD4+CD25+ regulatory T cells promoted a tumor-specific immunoresponse in pancreas cancer-bearing mice. Ann Surg Oncol. 2006;13:1252-8. doi: 10.1245/s10434-006-9015-y

16. Nagai H, Horikawa T, Hara I, Fukunaga A, Oniki S, Oka M, et al. In vivo elimination of $\mathrm{CD} 25$ + regulatory cells leads to tumor rejection of B16F10 melanoma, when combined with interleukin-12 gene transfer. Exp Dermatol. 2004;13:613-20. doi: 10.1111/j.0906-6705.2004.00198.x

17. Fontenot JD, Gavin MA, Rudensky AY. Foxp3 programs the development and function of CD4+CD25+ regulatory T cells. Nat Immunol. 2003;4:330-6. doi: 10.1038/ni904

18. Shevach EM. CD4+CD25+ suppressor T cells: more questions than answers. Nat Rev Immunol. 2002;2:389-400. doi: $10.1038 / \mathrm{nri} 821$

19. Tang Q, Bluestone JA. The Foxp $3^{+}$regulatory $T$ cell: a jack of all trades, master of regulation. Nature Immunol. 2008;9: 239-44. doi: 10.1038/ni1572

20. Seliger B. Strategies of tumor immune evasion. BioDrugs. 2005;19:347-54. DOI: 10.2165/00063030-200519060-00002

21. Stewart TJ, Abrams SI. Altered immune function during longterm host-tumor interactions can be modulated to retard autochthonous neoplastic growth. J Immunol. 2007;179:2851-9. doi: 10.4049/jimmunol.179.5.2851

22. Tao T, Ma X, Yang J, Zou JY, Ji SM, Tan YS, et al. Humanized anti-CD25 monoclonal antibody treatment of steroid-refractory acute graft-versus-host disease: a Chinese single-center experience in a group of 64 patients. Blood Cancer J. 2015; 5:e308. doi: 10.1038/bcj.2015.33

23. Jurin A, Jukić T, Ivanković S, Jurin M. Metastases development following local tumor treatment. Folia Biol (Praha). 2009;55: 177-82. PMID: 19863845

24. Jukić T. The influence of tumor on organism's immune reactivity. The role of regulatory $\mathrm{T}$ lymphocytes. $\mathrm{PhD}$ thesis. Josip Juraj Strossmayer University of Osijek, Faculty of Medicine, Osijek, 2010. (in Croatian)

25. Huss DJ, Pellerin AF, Collette BP, Kannan AK, Peng L, Datta $\mathrm{A}$, et al. Anti-CD25 monoclonal antibody Fc variants differentially impact Treg cells and immune homeostasis. Immunology. 2016:148:276-86. doi: 10.1111/imm.12609

26. Tatsumi T, Kierstead LS, Ranieri E, Gesualso L, Schena FP, Finke JH, et al. Disease-associated bias in T helper type 1 (Th1)/Th2 $\mathrm{CD}^{+}{ }^{+} \mathrm{T}$ cell responses against MAGE-6 in HLADRB $10401^{+}$patients with renal cell carcinoma or melanoma. J Exp Med. 2002;196:619-28. doi: 10.1084/jem.20012142

27. Liyanage UK, Moore TT, Joo HG, Tanaka Y, Herrmann V, Doherty G, et al. Prevalence of regulatory $\mathrm{T}$ cells is increased in peripheral blood and tumor microenvironment of patients with pancreas or breast adenocarcinoma. J Immunol. 2002; 169:2756-61. doi: 10.4049/jimmunol.169.5.2756

28. Somasundaram R, Jacob L, Swoboda R, Caputo L, Song H, Basak S, et al. Inhibition of cytolytic $\mathrm{T}$ lymphocyte prolifera- tion by autologous $\mathrm{CD}^{+} / \mathrm{CD} 25^{+}$regulatory $\mathrm{T}$ cells in colorectal carcinoma patients is mediated by transforming growth factor-beta. Cancer Res. 2002;62:5267-72. PMID: 12234995

29. Hellstrom I, Hellstrom KE. Studies on cellular immunity and its serum-mediated inhibition in Moloney-virus-induced mouse sarcoma. Inter J Cancer. 1969;4:587-600. doi: 10.1002/ ijc. 2910040503

30. Hellstrom I. A colony inhibition (CI) technique for demonstration of tumor cell destruction by lymphoid cells in vitro. Inter J Cancer. 1967;2:65-8. doi: 10.1002/ijc.2910020111

31. Jurin M, Suit HD. In vivo and in vitro studies of the influence of the immune status of $\mathrm{C} 3 \mathrm{Hf} / \mathrm{Bu}$ mice on the effectiveness of local irradiation of a methylcholanthrene-induced fibrosarcoma. Cancer Res. 1972;32:2201-11. PMID: 5080765

32. Jurin M, Suit HD. In vitro activity of lymphocytes and serum of $\mathrm{C} 3 \mathrm{Hf} / \mathrm{Bu}$ mice during the growth of methylcholanthreneinduced tumor and its regression following local irradiation. Cancer Res. 1974;34:672-8. PMID: 4814987

33. Jurin M. Antitumor action of sera and/or lymphocytes of mice bearing fibrosarcoma. Transpl Proc. 1975;7(Suppl 1):509.

34. Siddiqui SA, Frigola X, Bonne-Annee S, Mercader M, Kuntz $\mathrm{SM}$, Krambeck AE, et al. Tumor-infiltrating Foxp3- CD4+ CD25+ $\mathrm{T}$ cells predict poor survival in renal cell carcinoma. Clin Cancer Res. 2007;13:2075-81. doi: 10.1158/1078-0432. CCR-06-2139

35. Sutmuller RPM, van Duievenvoorde L, van Elsas A, Schumacher TN, Wildenberg ME, Allison JP, et al. Synergism of cytotoxic $\mathrm{T}$ lymphocyte-associated antigen 4 blockade and depletion of $\mathrm{Cd} 25^{+}$regulatory $\mathrm{T}$ cells in antitumor therapy reveals alternative pathways for suppression of autoreactive cytotoxic $\mathrm{T}$ lymphocyte response. J Exp Med. 2001;194:823-32. doi: 10.1084/jem.194.6.823

36. Curiel TJ, Wei S, Dong H, Alvarez X, Cheng P, Mottram P, et al. Blockade of B7-H1 improves myeloid dendritic cell-mediated antitumor immunity. Nature Med. 2003;9:562-7. doi: 10.1038/nm863

37. Son CH, Bae JH, Shin DY, Lee HR, Jo WS, Yang K, et al. Combination effect of regulatory $\mathrm{T}$-cell depletion and ionizing radiation in mouse models of lung and colon cancer. Int $\mathrm{J}$ Radiat Oncol Biol Phys. 2015;92(2):390-8. doi: 10.1016/j. ijrobp.2015.01.011

38. Rosenberg SA, Restifo NP, Yang JC, Morgan RA, Dudley ME. Adoptive cell transfer: a clinical path to effective cancer immunotherapy. Nat Rev Cancer. 2008;8:299-308. doi: 10.1038/ nrc2355

39. Sun JC, Bevan MJ. Defective CD8 T cell memory following acute infection without CD4 help. Science. 2003;300:339-42. doi: $10.1126 /$ science. 1083317

40. Shedlock DJ, Shen H. Requirement for CD4 T cell help in generating functional CD8 cell memory. Science. 2003; 300:337-9. doi: 10.1126/science. 1082305

41. Ramsburg EA, Publicover JM, Coppock D, Rose JK. Requirement for CD4 T cell help in maintenance of memory CD8 $\mathrm{T}$ cell responses is epitope dependent. J Immunol. 2007;178: 6350-8. doi: 10.4049/jimmunol.178.10.6350 


\section{Sažetak \\ ULOGA REGULATORNIH T LIMFOCITA U IMUNOSNOJ KONTROLI MC-2 FIBROSARKOMA}

\section{T. Jukic, A. Jurin Martic, S. Ivankovic, M. Antica, D. Pavan Jukic, C. Rotim i M. Jurin}

Uloga T regulatornih limfocita dobro je poznata, osobito kod tumora. Cilj ovoga istraživanja bio je utvrditi doprinos ovih limfocita u regulaciji antitumorske imunosti $\mathrm{CBA} / \mathrm{HZgr}$ miševa protiv $\mathrm{MC}-2$ fibrosarkoma (4. generacija metilkolantrenom izazvanog tumora). Razine T limfocita (CD4+, CD8+ and CD4+CD25+) određivale su se 8 i 20 dana nakon transplantacije tumora. Nadalje, uloga CD4+CD25+ T limfocita $\left(\mathrm{T}_{\mathrm{reg}}\right)$ u interakciji tumora i domaćina procijenjena je in vitro i in vivo primjenom specifičnih monoklonskih protutijela. Utvrdili smo da splenociti kako kontrolnih miševa tako i miševa s tumorom bez $\mathrm{T}_{\text {reg }}$ snažno, ali različito suzbijaju rast tumorskih stanica in vitro. Dok su splenociti netretiranih miševa pokazivali značajno smanjenje ove aktivnosti (sa 74,4\% na 62,6\% i 32,95\%), splenociti miševa bez $\mathrm{T}_{\text {reg }}$ pokazivali su porast ove aktivnosti (sa 79,5\% na 84,3\% i 86,2\%) od 6. do 13. i 21. dana nakon transplantacije tumora. Uz to, nakon i.v. injektiranja specifičnog monoklonskog anti- $\mathrm{T}_{\text {reg }}$ tumorskog protutijela neposredno prije intrakutane transplantacije tumorskih stanica, nakon početkog rasta nastupilo je odbacivanje tumora. Kod tretiranih miševa incidencija $T_{\text {reg }}$ stanica bila u početku vrlo niska i dostigla je normalne vrijednosti dva tjedna kasnije. Nakon četiri mjeseca pokazalo se da su ove životinje otporne na transplantaciju tumora.

Ključne riječi: Regulatorni T limfociti; Tumorski rast; Specifična monoklonska protutijela; Eksperimentalni miševi 